\title{
Low Viscosity Melamine Urea Formaldehyde Resin as a Bulking Agent in Reducing Formaldehyde Emission of Treated Wood
}

\author{
Rabiatol Adawiah Mohd Ali, ${ }^{a}$ Zaidon Ashaari, ${ }^{a, b}, *$ Seng Hua Lee, ${ }^{b}, *$ Mohd Khairun \\ Anwar Uyup, ${ }^{\mathrm{c}}$ Edi Suhaimi Bakar, ${ }^{\mathrm{a}}$ and Nur Izreen Farah Azmi ${ }^{\text {a }}$
}

\begin{abstract}
Melamine urea formaldehyde (MUF) resin impregnation followed by heat compression is a prominent method in improving mechanical properties and dimensional stability of wood. In addition, melamine is reactive to formaldehyde, and therefore able to reduce the free formaldehyde of the treated wood. This study aimed to produce compressed sesenduk (Endospermum diadenum) wood with low formaldehyde emission using low viscosity MUF resin. The effects of treatment efficiency on the physical and mechanical properties of the wood products were evaluated. The experimental design included impregnation of sesenduk strips with $20 \%$ and $30 \%$ MUF at five different formulations. Then, it was pre-cured at a temperature of $70{ }^{\circ} \mathrm{C}$ for $90 \mathrm{~min}$, followed by hot compression at $140{ }^{\circ} \mathrm{C}$ with the compression ratio of $80 \%$. The optimum treatment combination was determined through treatability, mechanical strength, dimensional stability, and formaldehyde emission. It was also compared to other treatments, including impregnation without further compression using formulated MUF and commercial MUF. The results revealed that F4 MUF, which consisted of $30 \%$ melamine, $50 \%$ formaldehyde, and $20 \%$ urea, was the optimal MUF formulation that resulted in low formaldehyde emission and acceptable physical and mechanical properties.
\end{abstract}

Keywords: Treatability; Impregnation; Formaldehyde emission; Sesenduk; Endospermum diadenum

Contact information: a: Faculty of Forestry, Universiti Putra Malaysia, 43400 UPM Serdang, Selangor, Malaysia; b: Institute of Tropical Forestry and Forest Products, Universiti Putra Malaysia, 43400 UPM Serdang, Selangor, Malaysia; c: Forest Product Division, Forest Research Institute Malaysia, 52109 Kepong, Selangor, Malaysia; *Corresponding authors: zaidon@upm.edu.my; lee_seng@upm.edu.my

\section{INTRODUCTION}

Owing to the depletion of timber resources, researchers are struggling to find alternative ways to reduce dependency on commercialized timber. Currently, their major concern is to utilize low-density hardwoods such as sesenduk (Endospermum diadenum), jelutong (Dyera costulata), mempening (Lithocarpus spp.), nyatoh or nangka kuning (Pouteria malaccensis), pauh kijang (Irvingia malayana), and petai (Parkia speciosa) (Lee and Zaidon 2015). In the wood industry, low-density wood generally is not preferable because its hygroscopicity towards moisture (Larjavaara and Muller-Landau 2010). When exposed to water or moisture, it becomes dimensionally unstable, and it is easily deteriorated by fungi or termites, which could further decrease the mechanical strength of the wood. The low-density woods need to be treated with chemicals to modify them into a high-value end product. A well-known method in timber modification is impregnation through vacuum-pressure using formaldehyde-based resin (Wan and Kim 2006; Wang et al. 2009). Previous studies have shown that impregnation treatment can remarkably 
improve the properties of treated wood in terms of mechanical properties, dimensional stability, and durability against biodeterioration agents (Gindl et al. 2003; Zhang et al. 2006; Kamke and Lee 2007; Örs et al. 2007; Izreen et al. 2011; Adawiah et al. 2012; Zaidon et al. 2016).

Formaldehyde-based resins, such as urea formaldehyde (UF), phenol formaldehyde $(\mathrm{PF})$, and melamine formaldehyde (MF), are widely used in the fabrication of wood polymer composites. According to Anisuzzaman et al. (2014), UF is commonly used as an adhesive in board making, MF and MUF are used as surface coating or laminating, while $\mathrm{PF}$ resins are mainly used in construction and building. However, a drawback of formaldehyde-based resins is that they emit formaldehyde, which is harmful to humans and environment. Formaldehyde emissions above $1.0 \mathrm{ppm}$ may irritate nose, eyes, throat, and cause extreme discomfort. Melamine formaldehyde (MF) is widely used in manufacturing of wood products or surface coating. However, due to its expensive price, urea was often introduced to form melamine urea formaldehyde (MUF). Application of MUF resin in impregnation of wood composites has been reported in recent years (Kutnar and Burnard 2014 and Cai et al. 2010).

Generally, synthesis of MUF involves addition of formaldehyde, melamine, and urea under an alkaline reaction, where methylated species are condensed into oligomeric or polymer molecules and water is released as a by-product (Jeong and Park 2016). The desired viscosity of the MUF resin highly depends on the end use of the wood-based composites, such as being used as adhesives. For example, $225 \mathrm{mPa} \cdot \mathrm{s}$ has been suggested for plywood and $250 \mathrm{mPa} \cdot \mathrm{s}$ for particleboard (Park et al. 2005; Abdullah and Park 2010). As there is limited information available on application of MUF resin as a bulking agent in impregnation treatment, this research was conducted to access the efficiency of MUF resin in enhancing physical and mechanical properties of the treated wood. This study was conducted to explore a new type of resin treatment in enhancing properties of low density wood. Simultaneously, it helps wood sectors to fully utilize low-density wood, and this may reduce dependency on Malaysian commercial timber. Treatability of sesenduk wood using low viscosity MUF at different formulations were determined. The effects of compression treatment using the formulated MUF were investigated relative to the physical properties, mechanical strength, and dimensional stability of the produced greener wood products, which had lower formaldehyde emissions (FE) of the compressed wood.

\section{EXPERIMENTAL}

\section{Materials}

Sesenduk wood (Endospermum diadenum) with density of 305 to $655 \mathrm{~kg} \cdot \mathrm{m}^{-3}$ was selected as substrate in this treatment. The timber was obtained from Ayer Hitam Forest Reserve, Puchong, Selangor, Malaysia. The wood was cut into strips with measurement of $200 \mathrm{~mm} \times 50 \mathrm{~mm} \times 5 \mathrm{~mm}$. Then they were air-dried to reach their equilibrium moisture content (EMC, approximately 15\%). Weight and dimension of each wood strip were recorded prior to treatment.

\section{Methods}

Preparation of MUF resin as a bulking agent 
The MUF resins were synthesized using 10 different formulations, which are shown in Table 1. The synthesis process was carried out in accordance with the procedure implemented by Awang Bono et al. (2003). A round-bottom flask with a capacity of 1000 $\mathrm{mL}$ equipped with three necks was connected to a condenser and motorized stirrer (500 $\mathrm{rpm}$ ). Initial temperature of water bath was set to $30^{\circ} \mathrm{C}$. Formaldehyde solution was poured into the flask, followed by urea granules (Urea 1), melamine powder, and distilled water. The mixture was blended homogeneously, and the initial $\mathrm{pH}$ and temperature were recorded. A few drops of sodium hydroxide (48\%) were applied to prevent quick polymerization and to achieve a $\mathrm{pH}$ of 8.8 to 9.0 (Pizzi 1994). The temperature was increased gradually for $10{ }^{\circ} \mathrm{C}$ in every $5 \mathrm{~min}$. When the temperature reached $80^{\circ} \mathrm{C}$, the solution was held for 1 hour. Then, the resin was let to cool down. At temperature of $65^{\circ} \mathrm{C}$, a second stage of urea (Urea 2) was added, and the solution was stirred for another 30 minutes. The final $\mathrm{pH}$ was adjusted to between 9.5 and 9.9 before the resin was cooled down to room temperature. Impregnation of wood strips was done using the formulated MUF and commercial MUF resin. The commercial MUF, which reacted as a control resin, was obtained from Aica Chemicals, Senawang, Negeri Sembilan, Malaysia. The formulated MUF had a viscosity of 6 to $9 \mathrm{cP}, \mathrm{pH}$ of 9.5 to 10.2, and a solids content of 21 to $36 \%$. Meanwhile, the commercial MUF has viscosity of $100 \mathrm{cP}, \mathrm{pH}$ of 9.1 and a solids content of $55.6 \%$.

Table 1. Formulations of Melamine Urea Formaldehyde (MUF) as Bulking Agent

\begin{tabular}{|c|c|c|c|c|c|}
\hline $\begin{array}{c}\text { Concentration of } \\
\text { MUF (\%) }\end{array}$ & Formulation & Melamine (\%) & Formaldehyde (\%) & Urea 1 (\%) & Urea 2 (\%) \\
\hline \multirow{5}{*}{20} & F1 & 30 & 60 & 5 & 5 \\
\cline { 2 - 6 } & F2 & 20 & 60 & 5 & 15 \\
\cline { 2 - 6 } & F3 & 20 & 55 & 10 & 15 \\
\cline { 2 - 6 } & F4 & 30 & 50 & 10 & 10 \\
\hline \multirow{5}{*}{30} & F5 & 25 & 55 & 7.5 & 12.5 \\
\cline { 2 - 6 } & F1 & 30 & 60 & 5 & 5 \\
\cline { 2 - 6 } & F3 & 20 & 60 & 5 & 15 \\
\cline { 2 - 6 } & F4 & 30 & 55 & 10 & 15 \\
\hline
\end{tabular}

Note: $\mathrm{MUF}=$ melamine urea formaldehyde

\section{Impregnation of wood strips}

All wood samples were measured for their dimension $\left(V_{\mathrm{i}}\right)$ and weight $\left(W_{\mathrm{i}}\right)$. The impregnation process was completed in a cylindrical impregnation chamber (custommade; Kuala Lumpur, Malaysia) using the empty cell process. Initially, all samples were immersed in a treating resin solution. A vacuum pressure of $85 \mathrm{kPa}$ was applied for $15 \mathrm{~min}$ and followed by pressure of $689 \mathrm{kPa}$ for $30 \mathrm{~min}$. After impregnation was completed, the resin solution was discharged, and the samples were taken out to remove excessive resin. The bulking agents used were synthesized MUF and commercial MUF. The impregnated strips with commercial MUF and untreated solid wood were used as the control sample 
Pre-curing and compression of impregnated wood

After the impregnation process, the wood strips were pre-cured at $70{ }^{\circ} \mathrm{C}$ for $90 \mathrm{~min}$. To complete polymerization of resin into wood cells, they were subjected to compression under high temperature. Initial thickness and weight of the pre-cured wood samples were measured prior to compressing. The strips were compressed at a temperature of $140{ }^{\circ} \mathrm{C}$ with an $80 \%$ compression ratio (CR) using a 4-mm-thick stopper bar. The compression was applied in three cycles by lifting the compression plate for a few seconds in 2 min increments to prevent excessive pressure and heat that could cause defects. The cured samples were then stored under controlled temperature and humidity conditions of $25 \pm 2$ ${ }^{\circ} \mathrm{C}$ and $65 \pm 2 \%$ relative humidity to achieve equilibrium moisture content (EMC) of the treated samples.

\section{Treatability of wood strips impregnated with MUF resin}

The efficiency of the resin in penetrating the wood cells can be measured by weight percent gain (WPG) and bulking coefficient (BC). Equations 1 and 2 were used to calculate these properties,

$$
\operatorname{WPG}(\%)=100\left[\left(W_{\mathrm{f}}-W_{\mathrm{i}}\right) / W_{\mathrm{i}}\right]
$$

where $W_{\mathrm{f}}$ equals the weight of conditioned samples after treatment $(\mathrm{g})$, and $W_{\mathrm{i}}$ equals the weight of conditioned samples before treatment $(\mathrm{g})$. Equation 2 is as follows,

$$
\mathrm{BC}(\%)=100\left[\left(V_{\mathrm{f}}-V_{\mathrm{i}}\right) / V_{\mathrm{i}}\right]
$$

where $V_{\mathrm{f}}$ equals the volume of conditioned samples after treatment $\left(\mathrm{mm}^{3}\right)$, and $V_{\mathrm{i}}$ equals the volume of conditioned samples before treatment $\left(\mathrm{mm}^{3}\right)$.

\section{Dimensional stability of wood strips when exposed to water soaking}

Dimensional stability of the treatment was evaluated based on water absorption (WA), thickness swelling (TS), and anti-swelling efficiency (ASE). Pre-weighed wood samples were cut into dimensions of $20 \mathrm{~mm} \times 20 \mathrm{~mm} \times 4 \mathrm{~mm}$ and were oven-dried at 103 $\pm 2{ }^{\circ} \mathrm{C}$ until constant weight. They were immersed in distilled water for $24 \mathrm{~h}$, and then the weight and volume of the samples were recorded (Ashaari et al. 1990). The WA, TS, and ASE calculations are shown in Eqs. 3 to 5,

$$
\operatorname{TS}(\%)=100\left[\left(T_{\mathrm{c}}-T_{\mathrm{t}}\right) / T_{\mathrm{c}}\right]
$$

where $T_{\mathrm{c}}$ equals the thickness gain in the treated wood after soaking $(\mathrm{mm})$, and $T_{\mathrm{t}}$ equals the thickness gain in the untreated wood in after soaking $(\mathrm{mm})$. Equation 4 is as follows,

$$
\operatorname{ASE}(\%)=100\left[\left(S_{\mathrm{c}}-\mathrm{S}_{\mathrm{t}}\right) / S_{\mathrm{c}}\right]
$$

where $S_{\mathrm{c}}$ equals the untreated volumetric swelling coefficient $\left(\mathrm{mm}^{3}\right)$, and $S_{\mathrm{t}}$ equals the treated volumetric swelling coefficient $\left(\mathrm{mm}^{3}\right)$. Equation 5 is as follows,

$$
S(\%)=100\left[\left(V_{2}-V_{1}\right) / \mathrm{V}_{1}\right]
$$

where $S$ equals the volumetric swelling coefficient $(\%), V_{1}$ equals the volume of the sample before wetting $\left(\mathrm{mm}^{3}\right)$, and $V_{2}$ equals the volume after wetting with water $\left(\mathrm{mm}^{3}\right)$.

\section{Mechanical properties of the treated and untreated wood}

The treated wood was also evaluated for modulus of rupture (MOR) and modulus of elasticity (MOE) in static bending and hardness. For the static bending test, British 
standard BS 373 (1957) was used with a modification of specimen size $(200 \mathrm{~mm} \times 50 \mathrm{~mm}$ $\times 4 \mathrm{~mm}$ ). The test was conducted using a universal testing machine (Instron 3300 series; Norwood, MA, USA) with a load capacity of $50 \mathrm{kN}$ at a constant speed of $6.4 \mathrm{~mm} / \mathrm{min}$. Central loading was applied at a span length of $180 \mathrm{~mm}$. The MOR and MOE were then calculated using Eqs. 6 and 7,

$$
\operatorname{MOR}\left(\mathrm{N} . \mathrm{mm}^{-2}\right)=P_{\mathrm{m}} \times \ell /\left(b \times d^{2}\right)
$$

where $P_{\mathrm{m}}$ equals the maximum load $(\mathrm{N}), \ell$ equals span $(\mathrm{mm}), b$ equals width of the sample $(\mathrm{mm})$, and $d$ equals the depth of the sample $(\mathrm{mm})$. Equation 7 is as follows,

$$
\operatorname{MOE}\left(\mathrm{N} . \mathrm{mm}^{-2}\right)=P_{\mathrm{L}} \ell^{3} / 4\left(b \times d^{3} \times \delta\right)
$$

where $P_{\mathrm{L}}$ represents the load at the limit of proportionality $(\mathrm{N}), \ell$ represents the span $(\mathrm{mm})$, $\delta$ is the deflection at mid-length at the limit of proportionality $(\mathrm{mm}), b$ is the width of the sample ( $\mathrm{mm})$, and $d$ represents the depth of the sample $(\mathrm{mm})$.

The Janka indentation test was performed in accordance to the British standard BS 373 (1957) with a modification of specimen size to $60 \mathrm{~mm} \times 40 \mathrm{~mm} \times 4 \mathrm{~mm}$. The steel ball had a diameter of 0.444 inches and the penetration of the hardness tool was set at 0.25 in/min.

\section{Evaluation of formaldehyde emission of wood test piece}

Formaldehyde emission was tested in accordance with MS 1787 (2005) using the desiccator method. Wood sample with total surface area of $1800 \mathrm{~cm}^{2}$ were prepared. Formaldehyde content of the solution was determined photometrically by the acetylacetone method. Then, the samples were placed in wire mesh in a desiccator with a specified volume of distilled water at a controlled temperature underneath for $24 \mathrm{~h}$. The distilled water was collected, then tested with acetylacetone ammonium acetate solution. The mixed solution was stored at room temperature for $1 \mathrm{~h}$ against the influence of light. Absorbance of the solution and background formaldehyde was determined at a wavelength of $412 \mathrm{~nm}$ against water using a spectrophotometer (Beckman Coulter DU 640; Beckman Coulter, Brea, CA, USA). The concentration of formaldehyde in the glass crystallizing dish in the desiccators due to the test piece was calculated using Eq. 8,

$$
G=f\left(A_{\mathrm{d}}-A_{\mathrm{b}}\right) \times 1800 / S
$$

where $G$ equals the concentration of formaldehyde due to test pieces $(\mathrm{mg} / \mathrm{L}), A_{\mathrm{d}}$ equals the absorbance of the solution from the desiccator containing the test pieces, $A_{\mathrm{b}}$ equals the absorbance of the background formaldehyde solution, $f$ equals the slope of the calibration curve for the standard formaldehyde solution $(\mathrm{mg} / \mathrm{L})$, and $S$ equals the surface area of the test pieces $\left(\mathrm{cm}^{2}\right)$.

\section{Scanning electron microscopic (SEM) analysis}

The morphologies of the MUF-treated and untreated samples were analyzed using a Hitachi S-3400N (Hitachi, Ltd., Tokyo, Japan) scanning electron microscope (SEM). Through SEM analysis, the degree of resin penetration into the wood cells as well as the effect of hot compression may be discovered. The MUF-treated and untreated samples were carefully cut into cross-sections and then coated with gold alloy at the cutting surface using a Q150T S turbo-pumped sputter coater/carbon coater (Quorum Technologies Ltd., East Sussex, UK). 


\section{Analysis of chemical content using Fourier transform infrared-universal attenuated total} reflectance spectroscopy

Fourier transform infrared universal attenuated total reflectance (FTIR-UATR) spectroscopy (Thermo Nicolet 6700 FT-IR; ThermoFisher, Madison, WI, USA) was used to determine the chemical compound and changes that occurred to the wood structure after the treatment process. The FTIR-UATR spectra were recorded in the wavelength range from 4500 to $600 \mathrm{~cm}^{-1}$ with an Equinox 55 spectrometer, including a detector and an attached ATR unit. Sample preparations involved grinding the samples to a fine powder and dispersing them in a matrix. A resolution of $4 \mathrm{~cm}^{-1}$ and 32 scans per sample were used.

\section{Statistical analysis}

Statistical analysis was performed using the SPSS 16.0 (Statistical Package for Social Science) software (IBM Corp., Armonk, NY, USA). One-way analysis of variance (ANOVA) was used to analyze the difference in properties of compressed sesenduk strips produced from different treatment combinations. The mean separation of each property was analyzed using Tukey's honest significance test at $\mathrm{p} \leq 0.05$.

\section{RESULTS AND DISCUSSION}

\section{Properties of Compressed Sesensduk}

The treatability of compressed strips treated with different formulated MUF are shown in Table 2. The results clearly show that impregnation using the formulated MUF resin successfully enhanced the properties of wood, as indicated by the higher values of density, WPG, and BC after treatment. The initial density of sesenduk before treatment was in the range of approximately $358 \mathrm{~kg} \cdot \mathrm{m}^{-3}$ to $413 \mathrm{~kg} \cdot \mathrm{m}^{-3}$.

Table 2. Treatability of Compressed Sesenduk Strips Treated with Different Formulations of MUF

\begin{tabular}{|c|c|c|c|c|c|}
\hline $\begin{array}{c}\text { Concentration of } \\
\text { MUF } \\
(\%)\end{array}$ & Formulation & $\begin{array}{c}\text { Density Before } \\
\text { Treatment } \\
\left(\mathrm{kg} \cdot \mathrm{m}^{-3)}\right.\end{array}$ & $\begin{array}{c}\text { Density After } \\
\text { Treatment } \\
\left(\mathrm{kg} \cdot \mathrm{m}^{-3)}\right.\end{array}$ & $\begin{array}{c}\text { WPG } \\
(\%, \mathrm{w} / \mathrm{w})\end{array}$ & $\mathrm{BC}(\%)$ \\
\hline 20 & $\mathrm{~F} 1$ & 406 & $514.9^{\mathrm{DE}}$ & $27.47^{\mathrm{E}}$ & $3.75^{\mathrm{D}}$ \\
\hline 20 & $\mathrm{~F} 2$ & 396 & $513.6^{\mathrm{DE}}$ & $31.02^{\mathrm{DE}}$ & $5.53^{\mathrm{BCD}}$ \\
\hline 20 & $\mathrm{~F} 3$ & 358 & $506.9^{\mathrm{E}}$ & $31.67^{\mathrm{D}}$ & $5.14^{\mathrm{AB}}$ \\
\hline 20 & $\mathrm{~F} 4$ & 372 & $518.1^{\mathrm{DE}}$ & $44.36^{\mathrm{C}}$ & $5.01^{\mathrm{A}}$ \\
\hline 20 & $\mathrm{~F} 5$ & 392 & $504.3^{\mathrm{E}}$ & $30.29^{\mathrm{DE}}$ & $5.26^{\mathrm{ABCD}}$ \\
\hline 30 & $\mathrm{~F} 1$ & 404 & $527.6^{\mathrm{E}}$ & $30.64^{\mathrm{DE}}$ & $7.21^{\mathrm{ABC}}$ \\
\hline 30 & $\mathrm{~F} 2$ & 406 & $579.1^{\mathrm{C}}$ & $42.76^{\mathrm{C}}$ & $6.28^{\mathrm{BCD}}$ \\
\hline 30 & $\mathrm{~F} 3$ & 377 & $589.3^{\mathrm{BC}}$ & $54.93^{\mathrm{A}}$ & $7.76^{\mathrm{ABCD}}$ \\
\hline 30 & $\mathrm{~F} 4$ & 400 & $611.8^{\mathrm{A}}$ & $49.62^{\mathrm{B}}$ & $6.43^{\mathrm{CD}}$ \\
\hline 30 & $\mathrm{~F} 5$ & 413 & $601.2^{\mathrm{AB}}$ & $45.63^{\mathrm{C}}$ & $6.20^{\mathrm{BCD}}$ \\
\hline
\end{tabular}

*Means followed by the same letter are not significantly different at $p \leq 0.05 ; B C=$ Bulking coefficient and WPG = weight percent gain 
After treatment, the density of compressed sesenduk increased as much as $27 \%$ to $45 \%$ and $31 \%$ to $55 \%$ for $20 \%$ and $30 \%$ MUF concentration, respectively. The WPG also increased with increasing MUF concentration, where 30\% MUF (31\% to 55\%) exhibited higher weight gain compared to $20 \%$ MUF (27\% to $44 \%$ ). Meanwhile, the BC of $30 \%$ MUF (6\% to $8 \%$ ) was slightly higher than $20 \%$ MUF ( $4 \%$ to $6 \%$ ).

Treatability data displayed in Table 2 indicate that F3 and F4 resulted in the best result in terms of WPG and BC. Therefore, sesenduk wood strips were treated with $20 \%$ and $30 \%$ MUF of F3 and F4 without compression (denoted as formulated MUFuncompressed wood). Comparison were made between these formulated MUFuncompressed woods with formulated MUF-compressed wood at the same concentration, commercial MUF uncompressed wood, and untreated sesenduk strips. The results listed in Table 3 clearly show that treatment without compression using formulated MUF had better properties compared to other treatments. Among all the formulated MUF, the formulation F4 was the optimal formulation indicated by the highest value of WPG. The untreated sesenduk had the lowest density of $402 \mathrm{~kg} . \mathrm{m}^{-3}$, followed by formulated MUF-compressed wood (531 to $616 \mathrm{~kg} \cdot \mathrm{m}^{-3}$ ), and commercial MUF uncompressed wood with $634 \mathrm{~kg} \cdot \mathrm{m}^{-3}$. Meanwhile, the highest density gained after treatment was found in the treatment with formulated MUF without undergoing compression (645 to $742 \mathrm{~kg} . \mathrm{m}^{-3}$ ).

Table 3. Treatability of Compressed and Uncompressed Sesenduk Treated with Different Formulations of MUF and Commercial MUF

\begin{tabular}{|c|c|c|c|c|}
\hline \multicolumn{2}{|c|}{ Treatment Combination } & $\begin{array}{c}\text { Density } \\
\left(\mathrm{kg} . \mathrm{m}^{-3}\right)\end{array}$ & WPG (\%, w/w) & $\begin{array}{c}\text { BC } \\
(\%)\end{array}$ \\
\hline \multirow{4}{*}{ Formulated MUF-compressed wood } & $20 \% \mathrm{~F} 3$ & 531 & 17 & 5 \\
\cline { 2 - 5 } & $20 \% \mathrm{~F} 4$ & 572 & 22 & 5 \\
\cline { 2 - 5 } & $30 \% \mathrm{~F} 3$ & 602 & 27 & 8 \\
\cline { 2 - 5 } & $30 \% \mathrm{~F} 4$ & 616 & 33 & 6 \\
\hline \multirow{3}{*}{ Formulated MUF-uncompressed wood } & $20 \% \mathrm{~F} 3$ & 645 & 36 & 8 \\
\cline { 2 - 5 } & $20 \% \mathrm{~F} 4$ & 669 & 45 & 8 \\
\cline { 2 - 5 } & $30 \% \mathrm{~F} 3$ & 656 & 52 & 9 \\
\cline { 2 - 5 } & $30 \% \mathrm{~F} 4$ & 742 & 66 & 9 \\
\hline Commercial MUF-uncompressed wood & - & 634 & 27 & 5 \\
\hline Untreated control & - & 402 & - & - \\
\hline
\end{tabular}

*Means followed by the same letter are not significantly different at $p \leq 0.05$; BC = Bulking coefficient and WPG = weight percent gain

In terms of WPG, the formulated MUF-uncompressed wood also gained the highest values of $36 \%$ to $66 \%$, while treatment using commercial MUF (27\%) was comparable to formulated MUF-compressed wood (17\% to 33\%). Compressed sesenduk strips had lower WPG values, which may have been due to the resin squeezing out during hot-pressing. Treatment with the formulated MUF in this study was greater compared to results by Altun and Tokdemir (2016), who reported a $17 \%$ and $48 \%$ gain in WPG when impregnating scots pine and white poplar with MUF resin. Altun and Tokdemir (2016) also mentioned that $\mathrm{BC}$ resin with a lower viscosity could penetrate wood cells in greater amounts. However, in the current study, the BC was not affected by the viscosity, where treatment with formulated commercial MUF (higher viscosity) had comparable BC with formulated 
MUF-compressed wood in the range of $5 \%$ to $8 \%$. The formulated MUF-uncompressed wood had a slightly greater BC of $8 \%$ to $9 \%$.

Dimensional stability in terms of WA, TS, and ASE of compressed wood increased significantly, as shown in Table 4. 30\% F4 resulted in the lowest WA of 32\%. This shows that higher melamine content reduced water uptake. Interaction between formaldehyde and melamine will form hydrophobic molecules that are known as methylol melamines. This statement is supported by Pizzi and Mittal (2017), who stated that cured MF becomes insoluble, which contributes to dimensional stability of the treated wood. The TS of the treated wood ( $2 \%$ to $4 \%$ ) was significantly lower than the untreated wood (5\%). Regardless of formulation, the higher MUF concentration led to lower TS. The TS values were much lower compared to the TS of compreg sesenduk using low molecular weight phenol formaldehyde (LmwPF) as reported by Adawiah et al. (2012), which was 5.4\%. Positive values of ASE were found in compressed wood products, i.e., $30 \%$ to $47 \%$. The ASE values increased as the MUF concentration increased, indicating that the resin bulked the cell wall to a certain extent (Adawiah et al. 2012). The MF has the capability to penetrate the secondary cell wall and amorphous region of cellulose fibrils (Gindl et al. 2003). The resin then crosslinked upon being subjected to hot-pressing to form thermoset resin.

Table 4. Dimensional Stability Compressed Sesenduk Strips Treated with Different Formulations of MUF

\begin{tabular}{|c|c|c|c|c|}
\hline $\begin{array}{c}\text { Concentration of } \\
\text { MUF (\%) }\end{array}$ & Formula & $\begin{array}{c}\text { Water } \\
\text { Absorption (\%) }\end{array}$ & $\begin{array}{c}\text { Thickness } \\
\text { Swelling (\%) }\end{array}$ & $\begin{array}{c}\text { Anti-swelling } \\
\text { Efficiency (\%) }\end{array}$ \\
\hline 20 & F1 & $40.01^{\mathrm{C}} \pm 2.05$ & $3.6^{\mathrm{B}} \pm 1.30$ & $30.03^{\mathrm{C}} \pm 7.62$ \\
\hline 20 & $\mathrm{~F} 2$ & $44.81^{\mathrm{B}} \pm 2.73$ & $3.16^{\mathrm{BC}} \pm 0.93$ & $40.14^{\mathrm{B}} \pm 7.88$ \\
\hline 20 & $\mathrm{~F} 3$ & $45.26^{\mathrm{B}} \pm 2.47$ & $2.24^{\mathrm{C}} \pm 1.59$ & $40.36^{\mathrm{B}} \pm 7.70$ \\
\hline 20 & $\mathrm{~F} 4$ & $44.28^{\mathrm{B}} \pm 4.15$ & $2.21^{\mathrm{C}} \pm 0.96$ & $40.16^{\mathrm{AB}} \pm 7.25$ \\
\hline 20 & $\mathrm{~F} 5$ & $44.39^{\mathrm{B}} \pm 3.48$ & $3.64^{\mathrm{B}} \pm 0.80$ & $37.34^{\mathrm{B}} \pm 9.77$ \\
\hline 30 & $\mathrm{~F} 1$ & $36.47^{\mathrm{D}} \pm 3.28$ & $2.71^{\mathrm{BC}} \pm 0.62$ & $45.58^{\mathrm{AB}} \pm 9.07$ \\
\hline 30 & $\mathrm{~F} 2$ & $34.96^{\mathrm{DE}} \pm 3.14$ & $2.38^{\mathrm{C}} \pm 1.07$ & $44.21^{\mathrm{AB}} \pm 14.11$ \\
\hline 30 & $\mathrm{~F} 3$ & $34.57^{\mathrm{DE}} \pm 3.04$ & $2.61^{\mathrm{BC}} \pm 0.91$ & $42.14^{\mathrm{AB}} \pm 11.39$ \\
\hline 30 & $\mathrm{~F} 4$ & $31.79^{\mathrm{E}} \pm 4.29$ & $3.00^{\mathrm{BC}} \pm 1.03$ & $47.01^{\mathrm{AB}} \pm 11.90$ \\
\hline 30 & $\mathrm{~F} 5$ & $32.21^{\mathrm{E}} \pm 3.50$ & $2.76^{\mathrm{BC}} \pm 0.97$ & $47.93^{\mathrm{AB}} \pm 9.52$ \\
\hline Untreated control & - & $60.70^{\mathrm{A}} \pm 5.63$ & $4.71^{\mathrm{A}} \pm 0.70$ & - \\
\hline
\end{tabular}

*Means followed by the same letter are not significantly different at $p \leq 0.05$.

Table 5 displays the comparison between formulated MUF-uncompressed woods with formulated MUF-compressed wood treated using $20 \%$ and $30 \%$ of F3 and F4 MUF, commercial MUF uncompressed wood, and untreated sesenduk strips. Both treatments using formulated MUF managed to reduce WA and TS compared to untreated wood. However, uncompressed wood using formulated MUF had the lowest WA (28\% to 33\%) and TS $(0.1 \%$ to $0.5 \%)$ and correspondingly the highest ASE of $81 \%$ to $93 \%$. Commercial MUF-uncompressed wood also had a slightly lower WA and TS compared to untreated wood. These results suggested that MUF resin was more efficient in impregnation without compression in enhancing dimensional stability. 
For evaluation of mechanical properties, only four MUF formulations were selected, namely $20 \% \mathrm{~F} 3,20 \% \mathrm{~F} 4,30 \% \mathrm{~F} 3$, and 30\% F4 based on their efficiency on treatability and dimensional stability. The results in Table 6 show that the treatment successfully enhanced the mechanical properties of compressed wood as indicated by higher values of MOR and MOE compared to the untreated wood. The untreated wood had a MOR of $87.6 \mathrm{~N} . \mathrm{mm}^{-2}$, which is comparable to $20 \% \mathrm{~F} 4\left(86.8 \mathrm{~N} . \mathrm{mm}^{-2}\right)$ and $20 \% \mathrm{~F} 3(90.2$ $\mathrm{N} . \mathrm{mm}^{-2}$ ). Meanwhile, regardless of formulation, $30 \%$ MUF had a $17 \%$ increment of MOR over the untreated wood. The MOE of the MUF-compressed sesenduk was in the range of 8506 N.mm $m^{-2}$ to 10682 N.mm ${ }^{-2}, 27 \%$ to $59 \%$ higher than untreated wood.

Table 5. Dimensional Stability of Compressed and Uncompressed Sesenduk Treated with Different Formulations of MUF and Commercial MUF

\begin{tabular}{|c|c|c|c|c|}
\hline \multicolumn{2}{|c|}{ Treatment Combination } & WA (\%) & TS (\%) & ASE (\%) \\
\hline \multirow{4}{*}{ Formulated MUF-compressed wood } & $20 \%$ F3 & 45 & 2 & 40 \\
\cline { 2 - 5 } & $20 \%$ F4 & 44 & 2 & 40 \\
\cline { 2 - 5 } & $30 \%$ F3 & 35 & 3 & 42 \\
\cline { 2 - 5 } & $30 \%$ F4 & 32 & 3 & 47 \\
\hline \multirow{4}{*}{ Formulated MUF-uncompressed wood } & $20 \%$ F3 & 33 & 0.4 & 89 \\
\cline { 2 - 5 } & $20 \%$ F4 & 29 & 0.5 & 81 \\
\cline { 2 - 5 } & $30 \%$ F3 & 28 & 0.3 & 88 \\
\cline { 2 - 5 } & $30 \%$ F4 & 29 & 0.1 & 93 \\
\hline Commercial MUF-uncompressed wood & - & 58 & 2 & 28 \\
\hline Untreated control & - & 69 & 5 & - \\
\hline
\end{tabular}

*Means followed by the same letter are not significantly different at $p \leq 0.05$; WA $=$ water absorption; TS = thickness swelling; ASE = anti swelling efficiency

Table 6. Mechanical Properties Compressed Sesenduk Strips Treated with 20\% and $30 \%$ of F3 and F4 MUF

\begin{tabular}{|c|c|c|c|}
\hline $\begin{array}{c}\text { Treatment } \\
\text { Combination }\end{array}$ & $\operatorname{MOR}\left(\mathrm{N} \cdot \mathrm{mm}^{-2}\right)$ & $\operatorname{MOE}\left(\mathrm{N} \cdot \mathrm{mm}^{-2}\right)$ & Hardness (kN) \\
\hline $20 \%$ F3 & $90.2^{\mathrm{A}} \pm 13.27$ & $8506^{A} \pm 1029$ & $4.90^{\mathrm{AB}} \pm 0.54$ \\
\hline $20 \%$ F4 & $86.8^{A} \pm 19.92$ & $9049^{A} \pm 1958$ & $4.96^{\mathrm{AB}} \pm 0.63$ \\
\hline $30 \%$ F3 & $102.8^{\mathrm{A}} \pm 23.73$ & $10682^{A} \pm 2766$ & $4.52^{\mathrm{B}} \pm 0.37$ \\
\hline $30 \%$ F4 & $102.6^{\mathrm{A}} \pm 33.11$ & $9747^{A} \pm 3135$ & $4.35^{\mathrm{B}} \pm 0.68$ \\
\hline Untreated wood & $87.6^{A} \pm 9.02$ & $6720^{A} \pm 541$ & $5.96^{A} \pm 1.09$ \\
\hline
\end{tabular}

*Means followed by the same letter are not significantly different at $p \leq 0.05$; MOR $=$ modulus of rupture; $\mathrm{MOE}=$ modulus of elasticity

Comparisons were made between formulated MUF-uncompressed woods with formulated MUF-compressed wood, commercial MUF uncompressed wood, and untreated sesenduk strips, as shown in Table 7. Even though not significantly different, the formulated MUF-uncompressed wood had a slightly higher value $\left(96 \mathrm{~N} \cdot \mathrm{mm}^{-2}\right.$ to 105 N.mm $\left.{ }^{-2}\right)$ compared to compressed wood $\left(87 \mathrm{~N} . \mathrm{mm}^{-2}\right.$ to $\left.103 \mathrm{~N} \cdot \mathrm{mm}^{-2}\right)$ and commercial 
MUF-uncompressed wood (95 N.mm ${ }^{-2}$ ). A higher degree of improvement in the range of $27 \%$ to $59 \%$ was found in MOE properties compared to the untreated wood. The highest MOE was obtained for formulated MUF-compressed wood $(30 \% \mathrm{~F} 3)$ with $10682 \mathrm{~N} . \mathrm{mm}^{-2}$, followed by $30 \% \mathrm{~F} 4$ (9747 N.mm ${ }^{-2}$ ), and commercial MUF-uncompressed wood (9512 N.mm ${ }^{-2}$ ).

Table 7. Mechanical Properties Compressed and Uncompressed Sesenduk Treated with $20 \%$ and $30 \%$ of F3 and F4 MUF

\begin{tabular}{|c|c|c|c|c|}
\hline \multicolumn{2}{|c|}{ Treatment Combination } & $\begin{array}{c}\mathrm{MOR} \\
\left(\mathrm{N} . \mathrm{mm}^{-2}\right)\end{array}$ & $\begin{array}{c}\mathrm{MOE} \\
\left(\mathrm{N} \cdot \mathrm{mm}^{-2}\right)\end{array}$ & $\begin{array}{c}\text { Hardness } \\
(\mathrm{kN})\end{array}$ \\
\hline \multirow{4}{*}{ Formulated MUF-compressed wood } & $20 \% \mathrm{~F} 3$ & 90 & 8506 & 4.9 \\
\cline { 2 - 5 } & $20 \% \mathrm{~F} 4$ & 87 & 9049 & 5.0 \\
\cline { 2 - 5 } & $30 \% \mathrm{~F} 3$ & 103 & 10682 & 4.5 \\
\cline { 2 - 5 } & $30 \% \mathrm{~F} 4$ & 103 & 9747 & 4.4 \\
\hline \multirow{3}{*}{ Formulated MUF-uncompressed wood } & $20 \% \mathrm{F3}$ & 96 & 8697 & 5.0 \\
\cline { 2 - 5 } & $20 \% \mathrm{~F} 4$ & 100 & 8807 & 6.1 \\
\cline { 2 - 5 } & $30 \% \mathrm{F3}$ & 100 & 8873 & 5.2 \\
\cline { 2 - 5 } & $30 \% \mathrm{~F} 4$ & 105 & 9021 & 6.7 \\
\hline Commercial MUF-uncompressed wood & - & 94.5 & 9512 & - \\
\hline Untreated control & - & 88 & 6720 & 6 \\
\hline
\end{tabular}

*Means followed by the same letter are not significantly different at $p \leq 0.05$; MOR $=$ modulus of rupture; $\mathrm{MOE}=$ modulus of elasticity

The hardness values of compressed wood using MUF were in the range of $4.4 \mathrm{kN}$ to $5.0 \mathrm{kN}$. These values were lower than the untreated wood for $17 \%$ to $27 \%$. Treatment with MUF resin followed by compression at high temperature made the wood's surface become brittle. Other treatment combinations using formulated MUF without the compression process had comparable hardness values as the untreated wood. Uncompressed wood treated with $20 \%$ and $30 \% \mathrm{~F} 4$ had higher hardness compared to that of the untreated wood, which was $6.1 \mathrm{kN}$ and $6.7 \mathrm{kN}$, respectively. This showed that the application of MUF through the impregnation process without compression could enhance surface hardness of the treated wood. This statement is supported by the findings of Gindl et al. (2003) who found that hardness strength of Norway spruce was enhanced by a $2 \mathrm{~mm}$ depth of impregnation.

\section{Formaldehyde Emission}

Figure 1 shows that the FE value of the samples were in the range of $0.94 \mathrm{ppm}$ to $1.74 \mathrm{ppm}$. Even though concentration of MUF did not significantly affect the FE values, decrements in FE were observed in formulation F4 as higher melamine and lower formaldehyde content were used. According to the European Panel Industry, the permeable emission was categorized into E1 $(<0.1 \mathrm{ppm})$, E2 $(0.1$ to $1.0 \mathrm{ppm})$, and E3 (> 1 to 2.3 ppm). The 30\% F4 MUF belonged to the E2 class, while other formulations fell into the E3 class as per CEN EN 13986 (2005). It can be summarized that the presence of melamine in formaldehyde-based resin may reduce the FE to a permissible level. A previous study by Zhang et al. (2013) found that FE was reduced to $40 \%$ using MUF resin. The FE values 
obtained from the current study were significantly lower than the treatment using PF resin. Impregnation with LmwPF and addition of urea generated $8.7 \mathrm{ppm}$ to $44 \mathrm{ppm}$ (Gindl et al. 2003). Compreg wood products using LmwPF and addition of urea yield $2.6 \mathrm{ppm}$ to 11.8 ppm (Izreen et al. 2011). This phenomenon clearly shows that melamine had two advantages: greater reactivity to capture more formaldehyde, and its presence contributed to strong linkages in cured MUF that enhance bonding performance (Tohmura et al. 2001; Kim et al. 2006; Luo et al. 2015). Formation of methylene carbon to an amide (melamine ring) bond is more stable than methylene carbon to nitrogen (urea), which may release formaldehyde during a reverse methylation reaction. Reduction in FE may also be caused by elongation of curing time, which accelerates polymerization; however, the mechanical properties may be adversely affected (Zaidon et al. 2015).

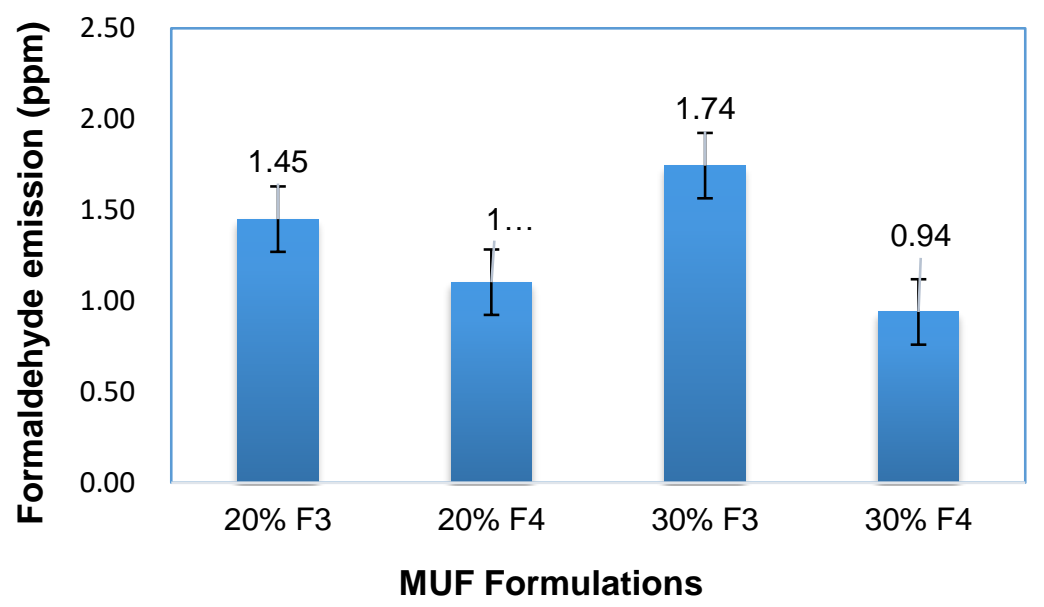

Fig. 1. Formaldehyde emission of sesenduk treated with different MUF resin formulations

\section{Micrographic View of Wood Cell Detected by SEM}

The degree of resin penetration into wood substrate may be qualitatively evaluated by comparing the micrograph of MUF-compressed and untreated wood samples. Figure 2(a) exhibits the cross-sectional micrograph of untreated wood that was empty from any resin occupancy. Meanwhile, Fig. 3(b) clearly shows most of the lumen and voids that were filled up with MUF resin, which indicated that penetration occurred. Penetration of MUF resin into the lumen cell causes the resin to remain within the cell and hence substitute $\mathrm{OH}$ groups, preventing water molecules from attack.
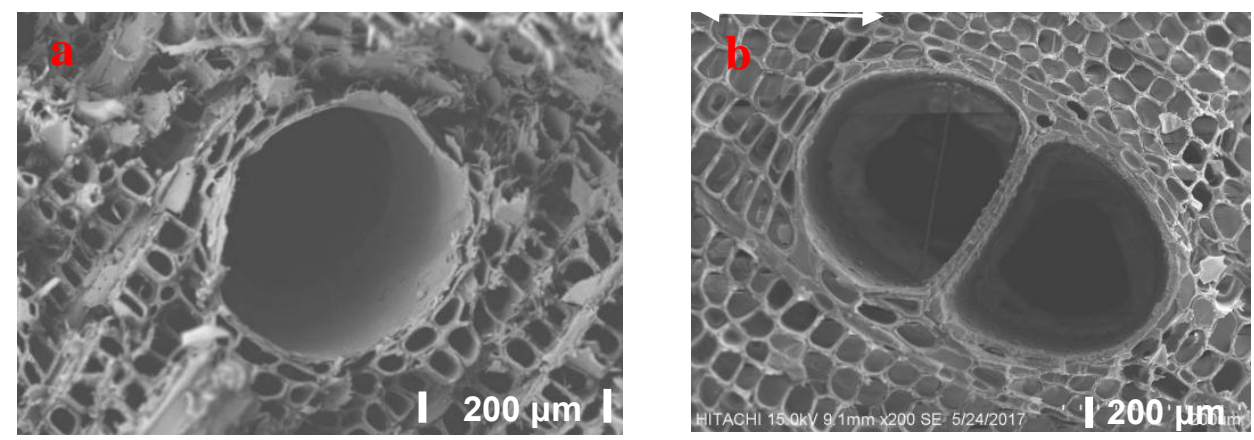

Fig. 2. SEM images of wood structure: (a) untreated wood, and (b) for the treated wood: lumen and voids filled up with MUF resin 
Deformation of wood substrate is clearly visible in the micrograph from Fig. 3. The deformation occurred resulting from compression at high temperature and pressure. The cracked cell wall resulting from pressure constrains the cell wall from swelling when exposed to moisture (Lee et al. 2015). The CR used in this study was 80\%; lowering the CR may cause massive rupture of the cell wall.

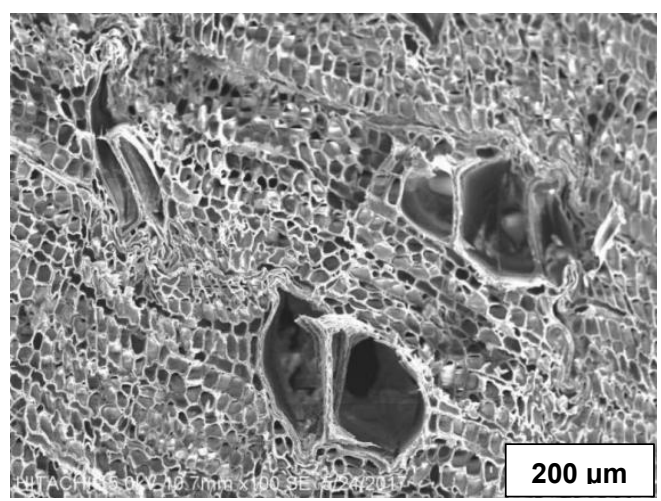

Fig. 3. Micrograph of the compressed wood: the vessel and fibre is deformed

\section{Spectroscopic Analysis of Chemical Content Detected by FTIR-UATR}

The MUF resin was formulated by mixing copolymers of melamine, urea, and formaldehyde. The main purpose was to reduce melamine content, to reduce material costs, and at the same time ensure that the resin worked well in improving product properties. Figure 4 shows the FTIR spectra analysis of MUF-compressed sesenduk samples.

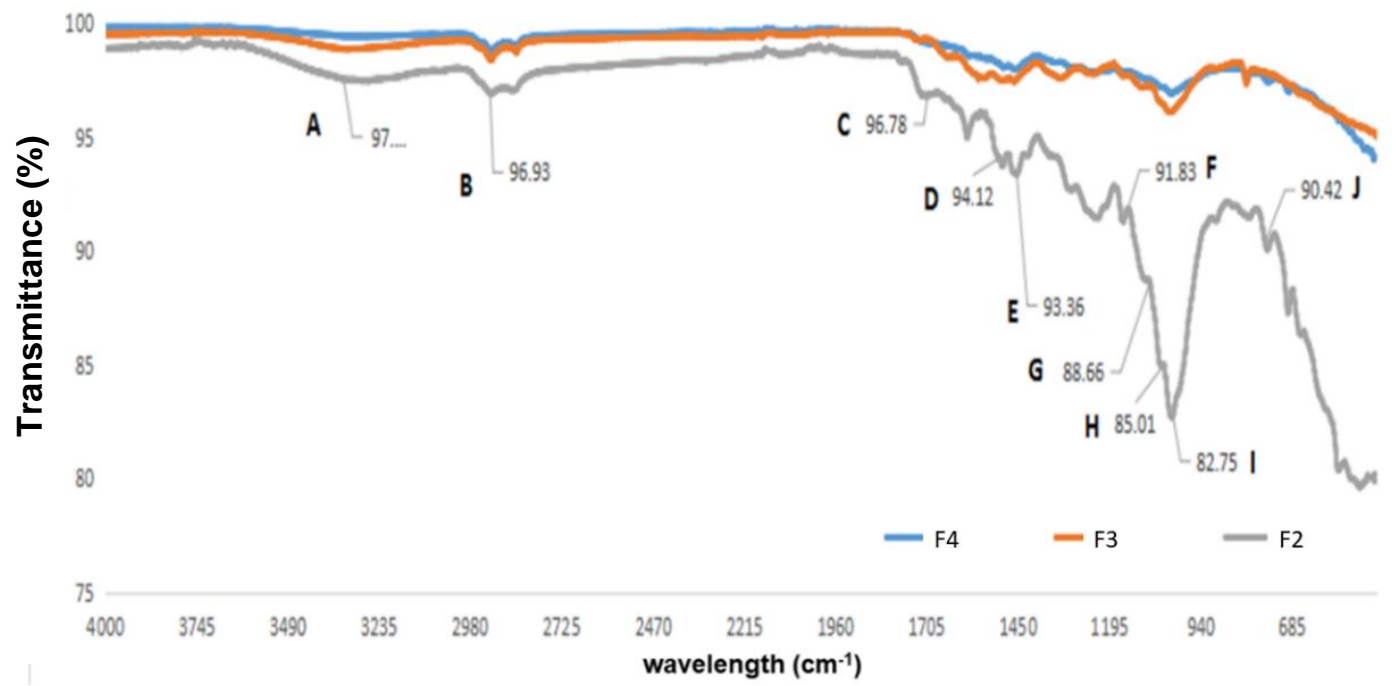

Fig. 4. FTIR spectra analysis of MUF-col Wavelength ( $\left.\mathbf{c m}^{-1}\right)$ nples. Note: $A, B, C, D, E, F, G, H, I, J$ denotes band numbers.

The synthesis process involved methylenation and condensation. Initially, weak alkaline was used to react melamine and formaldehyde to form methylol melamines. Then, polymerization occurred during condensation and transformed methylolmelamines and methylolureas to large oligomers containing methylene and methylene-ether bonds. Later, the curing process produced crosslinked networking structures. However, formaldehyde 
may have been released through dehydroxymethylation that increased formaldehyde emission. With the right MUF formulation, not only mechanical properties and dimensional stability were increased, but formaldehyde emission was also reduced to an acceptable level. This statement is supported by Sun et al. (2011) and Zhou et al. (2013), who found that a melamine ring structure increases the crosslink extent of the cured resin to form polymers with high bond strength.

Table 8 exhibits the presence of chemical compounds in the compressed wood based on previous studies (Poljansek and Matjaz 2005; Kandelbauer et al. 2007; Zhang et al. 2013). The presence of melamine was detected at a peak of $1044 \mathrm{~cm}^{-1}$ to $1043 \mathrm{~cm}^{-1}$, which is assigned to methylene linkages. The urea structure found at the peak of $1145 \mathrm{~cm}^{-}$ ${ }^{1}$ is referred to as an N-C-N symmetric stretch, and the peak at $3334 \mathrm{~cm}^{-1}$ is assigned to NH stretching of primary aliphatic amines. Furthermore, the presence of formaldehyde was detected from three peak locations. The peak of $760 \mathrm{~cm}^{-1}$ showed $\mathrm{C}=\mathrm{O}$ deformation of the NCON skeleton, $1018 \mathrm{~cm}^{-1}$ represents the $\mathrm{O}-\mathrm{H}$ bend, and $1704 \mathrm{~cm}^{-1}$ was appointed to $\mathrm{C}=\mathrm{O}$ stretch (overlapped with $\mathrm{OH}$ scissors of water). Reduction of formaldehyde emission was contributed by the formation of melamine formaldehyde bonds, which were apparent in a few areas. The peak of $2925 \mathrm{~cm}^{-1}$ showed the N-H secondary amine (stretching), $1802 \mathrm{~cm}^{-}$ ${ }^{1}$ represents C-O-C (ether group), $1455 \mathrm{~cm}^{-1}$ to $1454 \mathrm{~cm}^{-1}$ was appointed to methylene C$\mathrm{H}$ bending, and $1501 \mathrm{~cm}^{-1}$ was assigned to $\mathrm{C}=\mathrm{N}$ (ring vibration). A small band at $814 \mathrm{~cm}^{-1}$ represents stretching of a triazine ring of melamine (Sun et al. 2011; Gao et al. 2012). It can be concluded that with the right MUF formulation during the synthesis process, a stable MUF resin with low formaldehyde can be produced as in formulation F3 and F4 with higher melamine content and lower formaldehyde compared to F2.

Table 8. Summary of Chemical Compounds in MUF-compressed Wood Strips Referring to Data from Previous Studies on FTIR-ATR Analysis (Poljansek and Matjaz 2005; Kandelbauer et al. 2007; Zhang et al. 2013)

\begin{tabular}{|c|c|c|c|c|}
\hline Compound & $\begin{array}{l}\text { Literature Data of } \\
\text { Wavenumber } \\
\left(\mathrm{cm}^{-1}\right)\end{array}$ & $\begin{array}{c}\text { Observed } \\
\text { Wavenumber } \\
\left(\mathrm{cm}^{-1}\right)\end{array}$ & $\begin{array}{c}\text { Compound (Functional } \\
\text { Group) }\end{array}$ & $\begin{array}{c}\text { Band } \\
\text { Number } \\
s\end{array}$ \\
\hline Melamine & 1050 to 1030 & 1044 to 1043 & Methylene linkages (NCH2N) & $\mathrm{H}$ \\
\hline \multirow[b]{2}{*}{ Urea } & 1140 to 1190 & 1145 & $\mathrm{~N}-\mathrm{C}-\mathrm{N}$ symmetric stretch & $\mathrm{F}$ \\
\hline & 3350 to 3340 & 3334 & $\begin{array}{l}\mathrm{NH} \text { stretching of primary } \\
\text { aliphatic amines }\end{array}$ & A \\
\hline \multirow{3}{*}{ Formaldehyde } & 780 to 750 & 760 & $\begin{array}{c}\mathrm{C}=\mathrm{O} \text { deformation of NCON } \\
\text { skeleton }\end{array}$ & $J$ \\
\hline & 1025 to 1018 & 1018 & $\mathrm{O}-\mathrm{H}$ bend & 1 \\
\hline & 1722 & 1704 & $\begin{array}{c}\mathrm{C}=\mathrm{O} \text { stretch (overlapped with } \\
\mathrm{OH} \text { scissors of water }\end{array}$ & C \\
\hline \multirow{4}{*}{$\begin{array}{l}\text { Melamine } \\
\text { Formaldehyde }\end{array}$} & 2985 & 2925 & $\begin{array}{l}\mathrm{N}-\mathrm{H} \text { secondary amine } \\
\text { (stretching) }\end{array}$ & B \\
\hline & 1060 & 1802 & C-O-C (ether group) & $G$ \\
\hline & 1456 & 1455 to 1454 & Methylene $\mathrm{C}-\mathrm{H}$ bending & $E$ \\
\hline & 1530 & 1501 & $\mathrm{C}=\mathrm{N}$ (ring vibration) & $\mathrm{D}$ \\
\hline $\begin{array}{c}\text { Urea } \\
\text { Formaldehyde }\end{array}$ & 3346 to 3336 & 3334 & $\begin{array}{l}\text { O-H stretch and } \mathrm{N}-\mathrm{H} \\
\text { vibrations }\end{array}$ & $A$ \\
\hline
\end{tabular}




\section{CONCLUSIONS}

In this investigation, MUF resin with formulation 30\% F4 (30\% melamine, 50\% formaldehyde and $20 \%$ urea) was found to be the optimal formulation. Application of the formulated MUF through impregnation and compression treatment managed to enhance properties of sesenduk wood in terms of dimensional stability and mechanical strength. It was revealed that the wood treated with formulated MUF resin synthesized in this study performed better than the commercial MUF-treated wood. Nonetheless, impregnation treatment using the formulated MUF without compression was superior due to the fact that more resin was able to cure in situ at high temperature without being squeezed out. Impregnation with formulated MUF remarkably reduced swelling of wood samples up to $98 \%$, while compression treatment has reduced swelling up to $47 \%$ and followed by impregnation with commercial MUF (28\%). This phenomenon is in line with increasing of WPG and BC. Bulking of resin in lumen and voids were shown by SEM micrographs.

In terms of mechanical strength, similar trend of data was recorded. The highest MOR and hardness values were obtained from formulated MUF-uncompressed wood, followed by formulated MUF-compressed wood and commercial MUF-impregnated wood. Likewise, formaldehyde emission was reduced to E2 class (below $1.0 \mathrm{ppm}$ ). This was due to high melamine content of the resin that promote greater reactivity to capture free formaldehyde, which in return produced stronger linkages once the resin cured. This was shown by the FTIR-UATR analysis that spotted melamine formaldehyde bonds in few peaks. The results suggest that impregnation treatment using the formulated MUF can be served as a useful guideline in developing a new resin system. The new resin system offers saving on production cost and may produce excellent alternative wood products to reduce dependency on natural timber resources.

\section{ACKNOWLEDGMENTS}

This research was funded by the Higher Education Center of Excellence (HICoE), Ministry of Higher Education, Malaysia (Project Code: UPM/INTROP/100-13/9/3/HICoE (Vote No. 6369107)).

\section{REFERENCES CITED}

Abdullah, Z., and Park, B. D. (2010). "Influence of acrylamide copolymerization of ureaformaldehyde resin adhesives to their chemical structure and performance," J. Appl. Polym. Sci. 117(6), 3181-3186. DOI: 10.1002/app.32237

Adawiah, M. R. A., Zaidon, A., Izreen, F. N., Bakar, E. S., Hamami, S. M., and Paridah, M. T. (2012). "Addition of urea as formaldehyde scavenger for low molecular weight phenol formaldehyde-treated compreg wood," J. Trop. For. Sci. 24(3), 348-357.

Altun, S., and Tokdemir, V. (2016). "Modification with melamine formaldehyde and melamine-urea formaldehyde resin to improve the physical and mechanical properties of wood," BioResources 12(1), 586-596. DOI: 10.15376/biores.12.1.586-596 
Anisuzzaman, S. M., Bono, A., Krishnaiah, D., Maizura Ismail, N., and Mansuit, H. (2014). "The performance of melamine urea formaldehyde (MUF) based particleboard with wheat flour as filler," Jurnal Teknologi 68(1), 61-69. DOI: 10.11113/jt.v68.2026

Ashaari, Z., Barnes, H. M., Lyon, D. E., Vasishth, R. C., and Nicholas, D. D. (1990). "Effect of aqueous polymer treatments on wood properties. Part I: Treatability and dimension stability (IRG/WP-3611)," in: International Research Group on Wood Preservation, Stockholm, Sweden.

Bono, A., Beng, Y. K., and Siambun, N. J. (2003). "Melamine-urea-formaldehyde (MUF) resin: The effect of the number of reaction stages and mole ratio on resin properties," Jurnal Teknologi (Universiti Teknologi Malaysia) 38(F Jun.), 43052.

BS 373 (1957). "Methods of testing small clear specimens of timber," British Standard Institute (BSI), London, United Kingdom.

CEN EN 13986 (2005). "Wood-based panels for use in constructions - Characteristics, evaluation of conformity and marking," European Committee for Standardization (CEN), Brussels, Belgium.

Gao, Q., Shi, S. Q., Zhang, S., Li, J., Wang, X., Ding, W., Liang, K., and Wang, J. (2012). "Soybean meal-based adhesive enhanced by MUF resin," J. Appl. Polym. Sci. 125(5), 3676-3681. DOI: 10.1002/app.36700

Gindl, W., Zargar-Yaghubi, F., and Wimmer, R. (2003). "Impregnation of softwood cell walls with melamine-formaldehyde resin," Bioresource Technol. 87(3), 325-330. DOI: 10.1016/S0960-8524(02)00233-X

Izreen, F. N., Zaidon, A., Adawiah, M. R. T., Bakar, E. S., Paidah, M. T., Hamami, S. M., and Anwar, U. M. K. (2011). "Enhancing the properties of low-density hardwood Dyera costulata through impregnation with phenolic resin admixed with formaldehyde scavenger," J. Appl. Sci. 11(20), 3474-3481. DOI: 10.3923/jas.2011.3474.3481

Jeong, B., and Park, B. D. (2016). "Measurement of molecular weights of melamineurea-formaldehyde resins and their influences to properties of medium density fiberboards," J. Korean Wood Sci. Technol. 44(6), 913-922. DOI: 10.5658/WOOD.2016.44.6.913

Kamke, F. A., and Lee, J. N. (2007). “Adhesive penetration in wood-A review," Wood Fiber Sci. 39(2), 205-220.

Kandelbauer, A., Despres, A., Pizzi, A., and Taudes, I. (2007). "Testing by Fourier transform infrared species variation during melamine-urea-formaldehyde resin preparation,” J. Appl. Polym. Sci. 106(4), 2192-2197. DOI: 10.1002/app.26757

Kim, S., Kim, H. J., Kim, H. S., Lee, Y. K., and Yang, H. S. (2006). “Thermal analysis of viscoelastic properties and activation energy of melamine-modified ureaformaldehyde resins," J. Adhes. Sci. Technol. 20(8), 803-816. DOI: $10.1163 / 156856106777638671$

Larjavaara, M., and Muller-Landau, H. C. (2010). "Rethinking the value of high wood density," Functional Ecology 24(4), 701-705.

Lee, S. H., Lum, W. C., Zaidon, A., and Maminski, M. (2015). "Microstructural, mechanical and physical properties of post heat-treated melamine-fortified urea formaldehyde-bonded particleboard," Eur. J. Wood. Wood. Prod. 73(5), 607-616. DOI: 10.1007/s00107-015-0924-y 
Lee, S. H., and Zaidon, A. (2015). "Durability of phenolic-resin-treated sesenduk (Endospermum diadenum) and jelutong (Dyera costulata) wood against white rot fungus," Eur. J. Wood Wood Prod. 73(4), 553-555. DOI: 10.1007/s00107-015-0912-2

Luo, J., Zhang, J., Luo, J., Li, J., and Gao, Q. (2015). "Effect of melamine allocation proportion on chemical structures and properties of melamine-urea-formaldehyde resins," BioResources 10(2), 3265-3276. DOI: 10.15376/biores.10.2.3265-3276

MS 1787: PART 15 (2005). "Wood-based panels - Determination of formaldehyde emission by desiccator method," Department of Standards, Shah Alam, Malaysia.

Örs, Y., Keskin, H., Atar, M., and Colakoglu, M. (2007). "Effects of impregnation with Imersol-aqua on the modulus of elasticity in bending of laminated wood materials," Constr. Build. Mater. 21(8), 1647-1655. DOI: 10.1016/j.conbuildmat.2006.05.033

Park, B. D., Kang, E. C., and Park, J. Y. (2005). "Effects of formaldehyde to urea mole ratio on thermal curing behavior of urea-formaldehyde resin and properties of particleboard," J. Appl. Polym. Sci. 101(3), 1787-1792. DOI: 10.1002/app.23538

Pizzi, A., and Mittal, K. L. (2017). "Phenolic resin adhesives," in: Handbook of Adhesive Technology, $3^{\text {rd }}$ Edition, A. Pizzi, and K. L. Mittal (eds.), CRC Press, Boca Raton, FL, USA, pp. 541-571. DOI: 10.1201/9781315120942

Poljansek, I., and Krajnc, M. (2005). "Characterization of phenol-formaldehyde prepolymer resins by in line FT-IR spectroscopy," Acta Chim. Slov. 52(3), 238-244.

Sun, Q. N., Hse, C. Y., and Shupe, T. F. (2011). "Characterization and performance of melamine enhanced urea formaldehyde resin for bonding southern pine particleboard," J. Appl. Polym. Sci. 119(6), 3538-3543. DOI: 10.1002/app.33023

Tohmura, S. I., Inoue, A., and Sahari, S. H. (2001). "Influence of the melamine content in melamine-urea-formaldehyde resins on formaldehyde emission and cured resin structure," J. Wood Sci. 47(6), 451-457. DOI: 10.1007/BF00767897

Wan, H., and Kim, M. G. (2006). "Impregnation of southern pinewood and strands with low molecular weight phenol formaldehyde resins for stabilization of oriented strandboard," Wood Fiber Sci. 38(2), 314-324.

Wang, J., Deng, B., Wang, X., and Zheng, J. (2009). "Adsorption of aqueous Hg (II) by sulfur-impregnated activated carbon," Environ. Eng. Sci. 26(12), 1693-1699. DOI: 10.1089/ees.2008.0418

Zaidon, A., Lee, S. H., Rasmina, H., Roslinda, S., Mariani Ayu, O., and Shuhaibah, S. (2015). "Effects of extended heating time and post-urea treatment on formaldehyde emission and properties of phenolic compreg rubberwood," Pertanika Journal of Tropical Agricultural Science 38(4), 481-497.

Zaidon, A., Lee, S. H., and Zahali, M. R. (2016). "Performance of compreg laminated bamboo/wood hybrid using phenolic-resin-treated strips as core layer," Eur. J. Wood Wood Prod. 74(4), 621-624. DOI: 10.1007/s00107-016-1027-0

Zhang, J., Wang, X., Zhang, S., Gao, Q., and Li, J. (2013). "Effects of melamine addition stage on the performance and curing behavior of melamine-urea-formaldehyde (MUF) resin," BioResources 8(4), 5500-5514. DOI: 10.15376/biores.8.4.5500-5514

Zhang, Y. L., Zhang, S. Y., Yang, D. Q., and Wan, H. (2006). "Dimensional stability of wood-polymer composites,” J. Appl. Polym. Sci. 102(6), 5085-5094. DOI: 10.1002/app.23581 
Zhou, X., Pizzi, A., and Du, G. (2013). "Performance of MUF resins for particleboard before and after spray-drying," J. Adhes. Sci. Technol. 27(20), 2219-2225. DOI: 10.1080/01694243.2013.767152

Article submitted: Sept. 14, 2019; Peer review completed: Nov. 17, 2019; Revised version received and accepted: January 19, 2020; Published: February 5, 2020.

DOI: 10.15376/biores.15.2.2195-2211 